\title{
Cloning, nucleotide sequence and expression in Streptomyces lividans and Escherichia coli of pabB from Lactococcus lactis subsp. lactis NCDO 496
}

\author{
Francis F. ARHIN† and LeO C. VINING* \\ Department of Biology, Dalhousie University, Halifax, Nova Scotia, Canada B3H $4 J 1$
}

(Received 3 February 1993; revised 8 April 1993; accepted 10 May 1993)

\begin{abstract}
A gene (pabB) encoding the aminase activity of p-aminobenzoate (PABA) synthase in Lactococcus lactis subsp. lactis was cloned in pIJ41 and expressed in Streptomyces lividans strains defective in PABA biosynthesis. Expression of the gene was associated with a $1.2 \mathrm{~kb}$ deletion between the aph promoter and the cloning site in pIJ41. Subcloning in pBR322 and expression in Escherichia coli AB3295 of the cloned L. lactis DNA fragment localized the pabB-complementing gene in a $1.9 \mathrm{~kb}$ segment. The nucleotide sequence of this segment contained a 1410 bp open reading frame encoding a 470-amino-acid polypeptide of $50937 \mathrm{Da}$. The deduced amino acid sequence showed substantial similarity to those reported for PabB and TrpE from several organisms. Synonymous codon usage reflected the low $\mathbf{G}+\mathbf{C}$ content in the genomic DNA of $\boldsymbol{L}$. lactis subsp. lactis, and therefore differed markedly from the preferred usage in the $S$. lividans host. The cloned heterologous pabB DNA was expressed in amounts that allowed accumulation of excreted PABA in cultures of $S$. lividans transformants.
\end{abstract}

\section{Introduction}

Streptomycetes are filamentous, spore-forming members of the high guanine and cytosine $(\mathrm{G}+\mathrm{C})$ subgroup of Gram-positive bacteria (Stackebrandt \& Woese, 1981). Interest in their morphological development and in the numerous antibiotics and other secondary metabolites they produce has led to a rapid development of hostvector systems for gene cloning in these organisms (Bibb et al., 1983; Hunter, 1985; Tomich, 1988; Baltz, 1990); progress in defining the molecular requirements for efficient expression of cloned streptomycete genes has increased the versatility of these systems (Hopwood et al., 1986; Strohl, 1992). Streptomyces lividans appears to be relatively flexible in its requirements for transcriptional and translational control sequences (Bibb \& Cohen, 1982), and has the full complement of tRNAs needed to translate all 61 possible codons (Hopwood et al., 1986). The high (67-74\%) G+C content of strepto-

*Author for correspondence. Tel. (902) 494 2040; fax (902) 4943736.

†Present address: Centre de recherche en microbiologie appliquée, Institut Armand-Frappier, Université du Québec, 531 boulevard des Prairies, Ville de Laval, Quebec, Canada H7N $2 Z 3$.

Abbreviations: PABA, p-aminobenzoic acid.

The nucleotide sequence data reported in this paper have been submitted to GenBank and have been assigned the accession number M64860. mycete DNA is associated with more than $90 \% \mathrm{G}$ or $\mathrm{C}$ in the third position of codons (Bibb et al., 1985; Seno \& Baltz, 1991; Wright \& Bibb, 1992). In Escherichia coli, genes that are expressed naturally at high levels show a biassed codon usage that correlates with the availability of complementary isoaccepting tRNAs (Ikemura, 1981); this may be true in streptomycetes as well, although not yet proven. However, mismatches between tRNA availability and codon usage do not prohibit the expression of foreign genes. This is apparent not only from the expression of several genes from $E$. coli (Schottel et al., 1981; Chater et al., 1982; Kuhstos \& Rao, 1983; Shareck et al., 1984), but also of bovine, monkey and human genes (Gray et al., 1984; Muñoz et al., 1985; Pulido et al., 1986; Chang \& Chang, 1988; Lichenstein et al., 1988; Koller et al., 1989; Malek et al., 1990). The $G+C$ content of the genes expressed has ranged between $38.3 \%$ (human interleukin-2) to $67.6 \%$ ((monkey proinsulin).

The versatility of $S$. lividans as a nonrestricting host for cloning foreign DNA (Hopwood et al., 1987) and the availability of mutants deficient in PABA synthesis (Gil \& Hopwood, 1983; Paradkar, 1991) suggested that this species might be used to isolate and compare from a variety of organisms the PABA synthase genes associated with primary and secondary metabolism (Aidoo et al., 1990: Criado et al., 1993; Arhin \& Vining, 1993). In this paper, we report the expression in $S$. lividans of $p a b B$ from Lactococcus lactis subsp. lactis, an organism with a 
$\mathrm{G}+\mathrm{C}$ content $(37 \%)$ about one-half that of streptomycetes. We describe some characteristics of the lactococcal gene.

\section{Methods}

Bacterial strains and cloning vectors. Streptomyces lividans strains 66 (wild-type) and JG10 (pab) were provided by Drs D. A. Hopwood, John Innes Institute, Norwich, UK, and J. A. Gil, Universidad de Léon, Spain, respectively; strain AP3 (pab) was obtained in our laboratory by mutagenesis of $S$. lividans TK24 (Paradkar, 1991). The plasmid pIJ41, a low-copy-number vector constructed from the SLP1.2 replicon of Streptomyces coelicolor A3(2) (Thompson et al., 1982) was also a gift from Dr Hopwood. Lactococcus lactis subsp. lactis strain NCDO 496 was obtained from the National Council of Dairy Organisms, Reading, UK: strain AV117 is a plasmid-free derivative of strain NCDO 496 and was obtained in our laboratory (Aidoo, 1985). The sequencing vectors pBluescriptII SK( +$)$ and SK(-), and helper phage VCSM13 were from Stratagene. Escherichia coli strains AB3292 (proA2 his-4 pabAl ilvC7 argE3 thi-1) and AB3295 (his-4 pabB3 ilvC7 argE3 thi-1) were from the $E$. coli Genetic Stock Centre, Yale University School of Medicine, New Haven, CT, USA.

Chemicals and enzymes. Thiostrepton was a gift from S. J. Lucania of E. R. Squibb and Sons, New Brunswick, NJ, USA. Other biochemical agents, enzymes and culture components were purchased from commercial sources.

Media and culture conditions. Lactococcus lactis subsp. lactis strains were maintained on M17 agar (Terzaghi \& Sandine, 1975). Cells for DNA isolation were grown in M17 medium (500 ml per $2000 \mathrm{ml}$ Erlenmeyer flask) for $24 \mathrm{~h}$ at $27^{\circ} \mathrm{C}$ without shaking (Terzaghi \& Sandine, 1975). S. lividans strains were maintained on potato-dextrose agar (BBL) containing $0.5 \%(\mathrm{w} / \mathrm{v})$ yeast extract. Spores were harvested from such cultures grown at $30^{\circ} \mathrm{C}$ and were stored as suspensions in $20 \%$ (v/v) glycerol at $-20^{\circ} \mathrm{C}$ (Hopwood et al., 1985). Cultures for plasmid isolation or vegetative inocula were initiated from spores. Unless stated otherwise, vegetative inocula were grown in liquid media at $30^{\circ} \mathrm{C}$ for $48 \mathrm{~h}$ on a rotary shaker $(220$ r.p.m.; $3.7 \mathrm{~cm}$ eccentricity), and used in amounts of $1 \%(\mathrm{v} / \mathrm{v})$ to initiate cultures.

Mycelium used for protoplast formation was from cultures $(25 \mathrm{ml}$ per $250 \mathrm{ml}$ Erlenmeyer flask) grown for $36-40 \mathrm{~h}$ in YEME medium (Hopwood et al., 1985) supplemented with $34 \%$ (w/v) sucrose, $5 \mathrm{mM}$ $\mathrm{MgCl}_{2}$ and $0.5 \%(\mathrm{w} / \mathrm{v})$ glycine. To demonstrate PABA formation, cultures ( $100 \mathrm{ml}$ per $2000 \mathrm{ml}$ Erlenmeyer flask) were grown for $5 \mathrm{~d}$ in glucose-isoleucine medium (Chatterjee et al., 1983). Cultures of $E$. coli used in plasmid isolation or to prepare competent cells were inoculated with a single colony and grown overnight ( $50 \mathrm{ml}$ per $250 \mathrm{ml}$ Erlenmeyer flask) at $37^{\circ} \mathrm{C}$ with shaking in Luria broth (Prival \& Magasanik, 1971).

Plasmid and genomic DNA isolation. Plasmid DNA from S. lividans or $E$. coli was isolated by the rapid alkaline lysis method of Kieser (1984). For larger amounts the procedure was scaled up 10-fold and was followed by caesium chloride-ethidium bromide density-gradient centrifugation. Genomic DNA from $L$. lactis subsp. lactis was isolated and purified by the procedure of Anderson \& McKay (1983).

Cloning of the pabB gene. Genomic DNA $(10 \mu \mathrm{g})$ from $L$. lactis subsp. lactis NCDO 496 was digested with $B c l$ I and mixed with a $B c l \mathrm{I}$ digest of pIJ41 $(2 \mu \mathrm{g})$. The DNA was precipitated with ethanol, washed twice with $70 \%$ ethanol and resuspended in ligation buffer $(20 \mathrm{mM}-$ Tris/ $\mathrm{HCl}, \mathrm{pH} 7.6,10 \mathrm{~mm}-\mathrm{MgCl}_{2}, 10 \mathrm{~mm}$-dithioerythritol, $0.6 \mathrm{~mm}$-ATP) at a concentration of $40 \mu \mathrm{g} \mathrm{ml}^{-1}$. After incubation with 1 unit of T4 DNA ligase it was used to transform protoplasts of $S$. lividans JG10 by the procedures of Hopwood et al. (1985). Thiostrepton-resistant transformants were replica-plated on minimal medium (Hopwood, 1967) containing $0.25 \mu \mathrm{g}$ sulphanilamide $\mathrm{ml}^{-1}$ to select clones overproducing PABA.

DNA hybridization. Genomic DNA fragments from restriction enzyme digests were separated by electrophoresis, transferred to a nylon membrane and hybridized with the $\left[\alpha-{ }^{32} \mathrm{P}\right] \mathrm{dCTP}-\mathrm{labelled} 6 \mathrm{~kb}$ $B g l$ II DNA fragment from $\mathrm{pDQ} 250$ in a solution at $65^{\circ} \mathrm{C}$ containing $5 \times$ SSPE $(1 \times$ SSPE is $0.18 \mathrm{M}-\mathrm{NaCl}, 0.01 \mathrm{~m}$-sodium phosphate and 1 mM-EDTA, pH 7.7), $5 \times$ Denhardt's solution (Denhardt, 1966), $0.5 \%$ (w/v) SDS and sheared herring sperm DNA $\left(100 \mu \mathrm{g} \mathrm{ml}^{-1}\right)$. The membrane was washed twice at $70^{\circ} \mathrm{C}$ for $15 \mathrm{~min}$ with the following solutions in sequence : $5 \times$ SSPE containing $0.1 \%(\mathrm{w} / \mathrm{v})$ SDS, $2 \times$ SSPE containing $0.1 \%(\mathrm{w} / \mathrm{v})$ SDS, and $0.1 \times$ SSPE containing $0.1 \%(\mathrm{w} / \mathrm{v})$ SDS. The stringency of the final wash should have removed DNA not possessing complete nucleotide sequence identity with the probe.

Analyses. Total aromatic amino compounds in culture broths were determined colorimetrically as described by Levine \& Fischbach (1951) but without dithionite reduction. Samples for thin-layer chromatography (TLC) were extracted from filtered broth at $\mathrm{pH} 5 \cdot 0$ with ethyl acetate. Chromatograms (silica gel Sil60 $\mathrm{F}_{254}$; E. Merck) were developed with benzene/acetic acid/water $(42: 24: 1$, by vol. and $\mathrm{n}$-butanol/acetic acid/water (12:3:5, by vol.). PABA was detected at $R_{F} 0.50$ and 0.75 , respectively, as a quenching zone under ultraviolet light $(254 \mathrm{~nm})$ and as a yellow zone when the chromatogram was sprayed with $1 \%(\mathrm{w} / \mathrm{v}) \mathrm{p}$-dimethylaminobenzaldehyde in ethanol/ conc. $\mathrm{HCl}(9: 1, \mathrm{v} / \mathrm{v})$.

Nucleotide sequencing. Restriction fragments were subcloned in pBluescriptII SK(+) and pBluescriptII SK(-), and ordered deletion clones were prepared; single-strand DNA was obtained by the procedure of Karger \& Jessee (1990). The nucleotide sequence of both strands of the cloned DNA was determined by the dideoxy chaintermination method of Sanger et al. (1977) using [ $\alpha^{35}$ S]dATP and a modified T7 DNA polymerase (Sequenase, United States Biochemical). Database searches in GenBank used the BLASTP program (Altschul et al., 1990).

\section{Results and Discussion}

\section{Cloning of the pabB gene}

Streptomyces lividans JG10 contains a mutation within the genes for PABA synthase; it exhibits an unambiguous requirement for PABA when grown in media supplemented at low concentration with a sulphonamide, which competitively inhibits the incorporation of PABA into folic acid (Gil \& Hopwood, 1983). When BcIIdigested genomic DNA from $L$. lactis subsp. lactis NCDO 496 was shotgun-cloned in pIJ41 and introduced into S. lividans JG10 ( $p a b$ ), one of 15000 thiostreptonresistance transformants was able to grow after transfer to a medium containing $0.25 \mu \mathrm{g}$ sulphanilamide (an unsubstituted sulphonamide) $\mathrm{ml}^{-1}$. The transformant contained a $32 \mathrm{~kb}$ recombinant plasmid (pDQ250) which also transformed $S$. lividans AP3 (pab) to PABA independence in cultures containing sulphanilamide. Restriction enzyme analysis of $\mathrm{pDQ} 250$ indicated that an $18.3 \mathrm{~kb}$ DNA fragment had been inserted into the $B c I I$ site of the vector, and that a $1.2 \mathrm{~kb}$ vector segment 


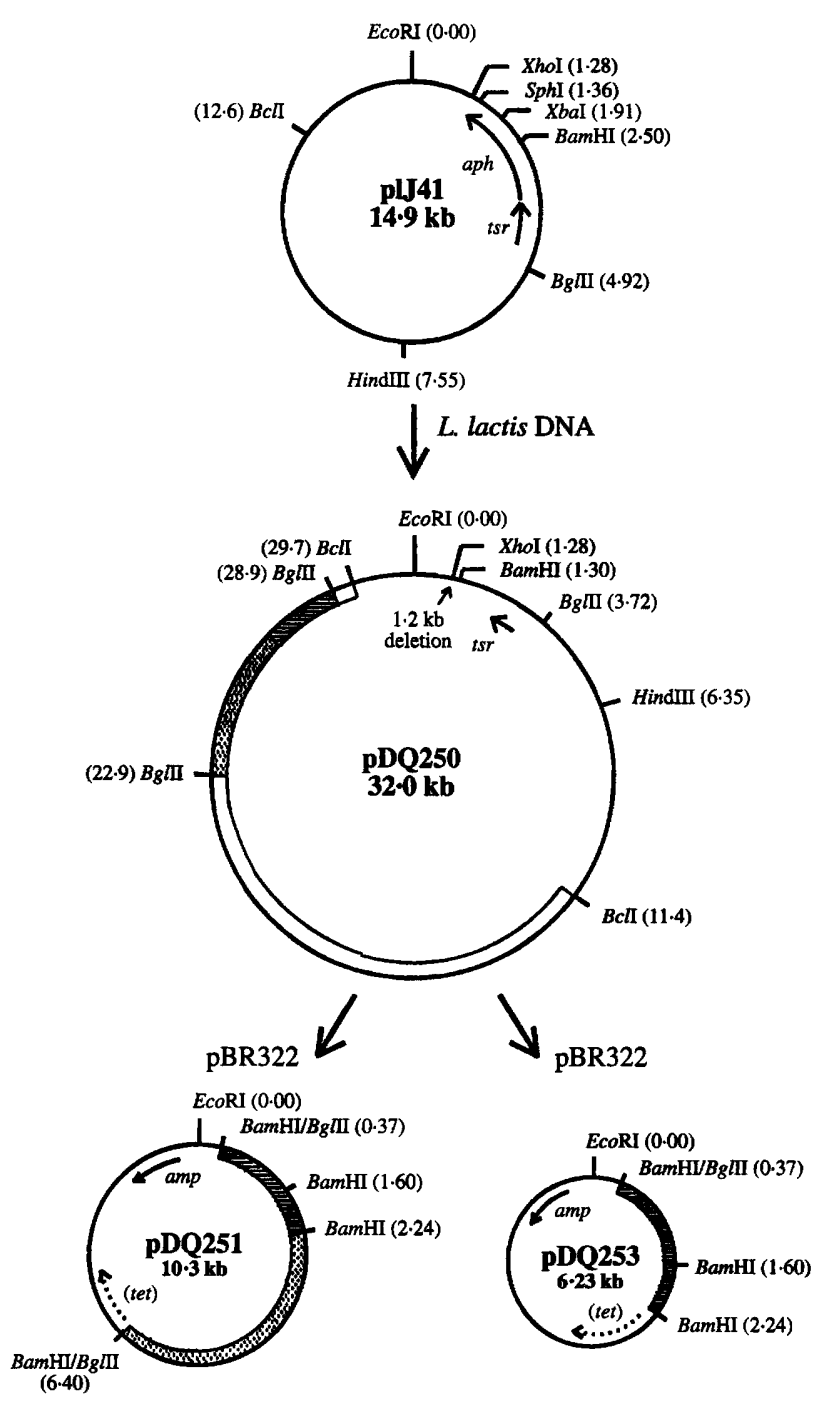

Fig. 1. Origin of pDQ250, pDQ251 and pDQ253. Shotgun-cloning of genomic DNA from $S$. lactis subsp. lactis NCDO496 in pIJ41 and selection in $S$. lividans for thiostrepton and sulphanilamide resistance yielded pDQ250. A $6.0 \mathrm{~kb} \mathrm{BglII}$ fragment from pDQ250 was cloned in pBR322; an ampicillin-resistant prototrophic transformant, selected in E. coli AB3295, yielded pDQ251. The $6 \cdot 0 \mathrm{~kb} B g l \mathrm{II}$ fragment from pDQ250 was partially digested with BamHI and ligated to pBR322 linearized with $B a m H I$; an ampicillin-resistant, prototrophic transformant of $E$. coli $\mathrm{AB} 3295$ yielded pDQ253. Vector sequences (pIJ41 or pBR322) are represented by single thin lines. DNA cloned from $L$. lactis is shown as a double line either cross-hatched (minimum pabBcomplementing region subcloned in pDQ253), stippled (remaining region subcloned in $\mathrm{pDQ} 251$ ) or open (remaining region initially cloned in pIJ41). Resistance genes are indicated by arrows showing the direction of transcription. Recognition sites for restriction enzymes on pIJ41 are redrawn from Thompson et al. (1982). The approximate location of the $1.2 \mathrm{~kb}$ deletion is indicated in $\mathrm{pDQ} 250$. The numbers in parenthesis are the positions (in $\mathrm{kb}$ ) of restriction enzyme sites relative to the EcoRI site $(0 \cdot 0)$.

containing the carboxy-terminus of the aph gene had been deleted (Fig. 1). Consistent with such a deletion, transformants containing $\mathrm{pDQ} 250$ differed from those containing pIJ41 in their failure to grow on media supplemented with neomycin. When the $18.3 \mathrm{~kb}$ insert was excised from pDQ250 by digestion with $B c l$ I and introduced into the $B c l \mathrm{I}$ site of pIJ41, the recombinant plasmid did not complement the pab mutations in $S$. lividans strains JG10 and AP3. This suggested that the insert lacked promoter activity in S. lividans and that the deletion in pDQ250 allowed pab expression from the $a p h$ promoter. Similar vector deletions allowing expression of E. coli genes in Streptomyces from Streptomyces vector promoters have been reported (Schottel et al., 1981; Shareck et al., 1984).

\section{Subcloning in E. coli}

A $6.0 \mathrm{~kb} B g l \mathrm{II}$ restriction fragment internal to the $18.3 \mathrm{~kb} \mathrm{Bcl}$ I insert was cloned in both orientations in the BamHI site of pBR322. The orientation in pDQ251 (see Fig. 1) complemented the $p a b B$ mutation in $E$. coli AB3295 but not the pabA mutation in E. coli AB3292 (The $p a b B$ and $p a b A$ gene products form the aminase and glutamine amidotransferase components, respectively, of PABA synthase. A mutation in either gene can prevent PABA synthesis.); the plasmid with the $6.0 \mathrm{~kb}$ fragment cloned in the opposite orientation did not complement either mutation. Complementation only when the fragment was cloned in a particular orientation suggested that $p a b B$ was again expressed from a vector promoter, presumably the tet promoter in pBR322. In support of this conclusion, a mixture of sulphanilamideresistant and -sensitive transformants was obtained when the $6.0 \mathrm{~kb} \mathrm{BglII}$ fragment was ligated to the $13.7 \mathrm{~kb}$ vector fragment obtained by digestion of $\mathrm{pDQ} 250$ with $B c l$, and the ligation mixture was used to transform $S$. lividans JG10 or AP3 protoplasts. Sulphanilamide resistance in the transformants correlated with the presence of a $19.7 \mathrm{~kb}$ plasmid (pDQ255) carrying the $6.0 \mathrm{~kb}$ insert oriented away from the $a p h$ promoter site. The $p a b B$ complementing sequence within the $6.0 \mathrm{~kb} B g l \mathrm{II}$ restriction fragment was localized by excision of the DNA from a $B g l \mathrm{II}$ digest of $\mathrm{pDQ} 250$, partial digestion with BamHI and ligation of the fragments into pBR322 linearized with BamHI. Transformation of $E$. coli AB3295 with the ligation mixture yielded a prototrophic strain containing a recombinant plasmid with a $1.87 \mathrm{~kb} \mathrm{BglII-BamHI}$ insert (see Fig. 1). The insert DNA complemented the $p a b B$ mutation when present in the BamHI site of pBR322 in the same orientation as in pDQ251; the plasmid was designated pDQ253.

A ${ }^{32} \mathrm{P}$-labelled sample of the $6.0 \mathrm{~kb} \mathrm{BglII}$ fragment of $L$. lactis DNA excised from the $B c l \mathrm{I}$ insert in $\mathrm{pDQ} 250$ hybridized with single $6.0 \mathrm{~kb}$ fragments in $B g l \mathrm{II}$ digests of genomic DNA from $L$. lactis subsp. lactis strains AV117 and NCDO 496. When $B c l$ I digests of the 
genomic DNA samples were used, the probe hybridized with single fragments of about $20 \mathrm{~kb}$. The evidence that the cloned DNA was present in the plasmid-free strain AV117 as well as in the wild-type strain NCDO 496 indicated that the fragment originated from the chromosome of $L$. lactis. The probe also hybridized with pDQ253, but not with the genomic DNA of streptomycetes. The results were consistent with the shotguncloning in pDQ250 of an $18.3 \mathrm{~kb} \mathrm{BclI}$ fragment from the genomic DNA of $L$. lactis subsp. lactis NCDO 496, and with the subcloning in $\mathrm{pDQ} 251$ of $6.0 \mathrm{~kb} B g l \mathrm{II}$ and $1.87 \mathrm{~kb} \mathrm{BglII}-$ Bam HI segments of this DNA, each of the recombinant plasmids conferring resistance to sulphanilamide.

\section{Production of $P A B A$ by $S$. lividans strains}

When grown as adjacent patches on minimal agar medium containing $0.25 \mu \mathrm{g}$ sulphanilamide $\mathrm{ml}^{-1}$, strains containing pDQ250 cross-fed the $S$. lividans pab mutants. Cultures of $S$. lividans JG10 (pab) and AP3 (pab) as well as their transformed derivatives containing pIJ41 or pDQ250 were grown in a defined medium, and clarified broths were examined for aromatic amines. Positive colorimetric assays were obtained only for the transformants containing pDQ250; the concentration of PABA in their cultures was $13-15 \mu \mathrm{g} \mathrm{ml}^{-1}$. When the broths of these strains were examined by TLC, zones were observed at the $R_{F}$ values and with the characteristics of authentic PABA. The results established that the $S$. lividans transformants with enhanced resistance to sulphanilamide overproduced PABA, and indicated that the cloned $L$. lactis subsp. lactis fragment was involved in PABA production.

\section{Nucleotide sequence analysis}

The nucleotide sequence of the $1.87 \mathrm{~kb} B g l \mathrm{II}-\mathrm{BamHI}$ fragment showed one large open reading frame (ORF) beginning with ATG at nucleotides 147-149 and terminating with TAA at nucleotides $1557-1559$ (Fig. 2). A putative ribosome-binding site (RBS) with a sequence GAAAGGA complementary to a region near the $3^{\prime}$ end of 16S rRNA of L. lactis subsp. lactis (Ludwig et al., 1985) was present upstream of and separated by five bases from the ATG start codon. The sequence and its separation from the translational start site fall within the range observed in streptomycetes (Strohl, 1992) and $E$. coli (Rosenberg \& Court, 1979), and are similar to RBSs recognized in lactococci (De Vos, 1987). The region upstream of the ORF contained no appropriately spaced hexamers corresponding to the consensus -10 and -35 promoter sequences recognized by the common sigma
1 AGATCTCTTATAGAATAGCAATGAAATCTTGGGCGTATACGTAATATACTGAATATATCA ATCGTATTGAGCATGGTATATCACTGIGCAAAGACATACGGACTGACTGAACAGTAGCGT GGCATAAGTCGATCGAAAAGAATTAGATGTTCACAATCAGTGGAGTAGTATIGATAACAA

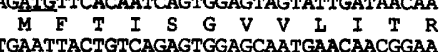
GACCAGTATACGATGAAGGAAGTTTGAATTACTGTCAGAGTGGAGCAATGAACAACGGAA
$P$
$\mathbf{V}$ $\begin{array}{llllllllllllllllllllllll}I & L & E & S & V & E & G & N & K & P & R & Y & S & I & G & G & A & E & P & I\end{array}$ TCGGAACTATCAACGCAAACGCAGTATTGACTGCAGCAACTTACGCAGAAGATGTAAAGT

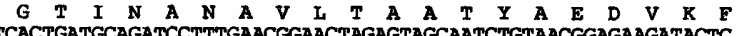
TCACTGATGCAGATCCTTTGAACGGACTAGAGTAGCAATCTGTAACGGAGAAGATACTC

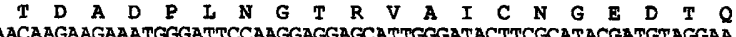
$\begin{array}{lllllllllllllllllllllllll}Q & E & E & M & G & F & Q & G & G & A & I & G & Y & F & A & Y & D & V & G & R\end{array}$ GAAGATTGGAAGGATACAACGATIG A I G $Y$ F A $Y$ D $G$ $\begin{array}{llllllllllllllllllll}R & \text { I } & \mathbf{E} & G & \mathbf{Y} & \mathbf{N} & \mathbf{D} & \mathbf{L} & \mathbf{G} & \mathbf{I} & \mathbf{E} & \mathbf{D} & \mathbf{W} & \mathbf{A} & \mathbf{I} & \mathbf{P} & \mathbf{D} & \mathbf{I} & \mathbf{A} & \mathbf{G}\end{array}$ $S$ S $Y$ E I G V S A D H $O$ CAC

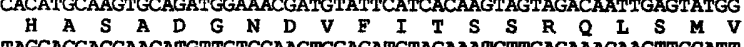
TAGCAGGACCAACATGTTGTGCAAGTGGAGATGTAGAAATCTTGAGAAACAAGTTGCAT'

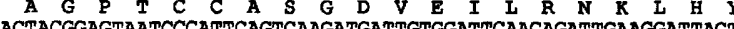

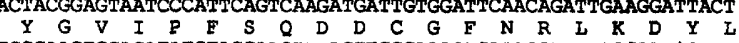

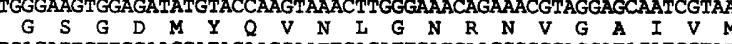
TGACATTGTTCCAAGGATACAACCAATTGAGATTGATGAACCCGGGACCATACATGGTAT $\begin{array}{llllllllllllllllllll}T & L & F & Q & G & Y & N & Q & L & R & I & M & N & P & G & P & Y & M & V & F\end{array}$

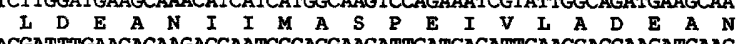
ACGATTTGAACACAAGACCAATCGCAGGAACATTGATGAGATTGAACGAGCAAGATGAAG $\begin{array}{llllllllllllllllllll}D & I & N & T & R & P & I & A & G & T & I & M & R & I & N & E & Q & D & E & D\end{array}$ ATGGAGTAAACGCAGCATGTCTGGGACAACATCATAAGGATAGAGCAGAACATATGATGA

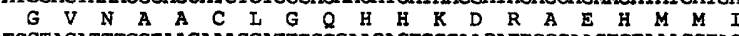
TCGTAGATTTGGTAAGAAACGATTTGGGAAGAGTGGGAAGATTCGGAAGTGTAAACGTAC

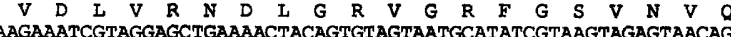

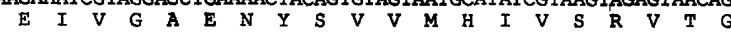
GATCCTTGAACGAAGCATTCGAAGCAATGGAAATCATCAGAGCAGGATTCCCAGGAGGAA

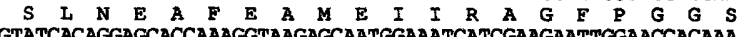

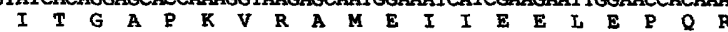
I TACGAGATGATGGGAGGAGTATCGGATACATCGCATACAGAGGAACATCG Q R

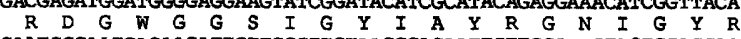
GAATCGCAATCAGACATTGTTCGCTTGIAACGGACAATTGTTCGCAAGTAGTGGAGCAG

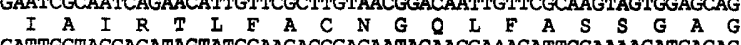
GATTGGTAGGAGATAGTATGGAAGACGGAGAATACAACGAAACATTCGAAAAGATGAGAG CATTGAGAAGTTTCTICTGTGCAGCGGTACATATGGGAAAGACACCATACTTGAGTTAAT

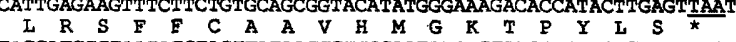
TACGATCCGTAATATGTACTTATAAGCGTTGCAATATGCGTAAGTAGTACTTAATTACGT TACGATCCGTATTTITAATAGTAATAGATCATGACTAGAATATCGATTGTAATAGATCTGATG TAATTAAATTCAGTATAATCGTATCATGACAAAATGCATGAATCGTTATCGGTAACTATA TAATTAAATTCAGTATAATCGTATCATGACAAAATGCATGAATCGTTATCGGTAACTATA ATGCTCAGTGATATGTGAATCGTATCCGTGCCTAGCGATTTAACTAAAGCTAGCATGATA ATTAGAATAGATAACTGATACAAATACTA

Fig. 2. The nucleotide and derived amino acid sequences of the pabBcontaining DNA fragment cloned from $L$. lactis subsp. lactis. The nucleotide/amino acid positions are numbered above the sequences. The putative RBS (nucleotides 135-141) as well as the start and stop codons are underlined.

factors of L. lactis, S. lividans and E. coli (McClure, 1985; De Vos, 1987; Strohl, 1992). This may indicate that the gene is transcribed from an upstream promoter that was not cloned with the fragment. However, the presence of a promoter region that deviates from the consensus, and possibly also requires for its function ancillary proteins that may be absent in S. lividans and E. coli (Irani et al., 1989), cannot be excluded. Either of these alternatives could explain why expression of the $L$. lactis gene in both $S$. lividans and $E$. coli required a vector promoter. A similar apparent requirement for vector promoters was observed when a citrate permease gene from $L$. lactis was cloned and expressed in $E$. coli; the cloned sequence did not contain any regions resembling $E$. coli or $L$. lactis consensus promoter sequences for transcription initiation (David et al., 1990). Lack of expression due to absence of appropriate promoter sequences in cloned DNA from $L$. lactis subspecies lactis containing genes 


\section{Table 1. Comparison of deduced amino acid sequences}

\begin{tabular}{|c|c|c|c|}
\hline Gene & $\begin{array}{c}\text { Identity } \\
(\%)\end{array}$ & $\begin{array}{c}\text { Overlap } \\
\text { (number of } \\
\text { amino acids) }\end{array}$ & Reference \\
\hline Streptomyces lividans pabB & 63 & 169 & Arhin \& Vining (1993) \\
\hline Bacillus subtilis pabB & 54 & 192 & Slock et al. (1990) \\
\hline Escherichia coli pabB & 53 & 198 & Goncharoff \& Nichols (1984) \\
\hline Salmonella typhimurium pabB & 52 & 198 & Goncharoff \& Nichols (1988) \\
\hline Klebsiella aerogenes pabB & 52 & 198 & Goncharoff \& Nichols (1988) \\
\hline Pseudomonas aeruginosa trpE & 46 & 197 & Essar et al. (1990) \\
\hline Bacillus subtilis trpE & 43 & 197 & Henner et al. (1984) \\
\hline Lactococcus lactis trpE & 41 & 205 & Bardowski et al. (1992) \\
\hline
\end{tabular}

for histidine or branched-chain amino acid biosynthesis may also have accounted for inconsistent complementation of his and ilv auxotrophy in Bacillus subtilis and E. coli (Delorme et al., 1992; Godon et al., 1992). However, an operon containing all of the genes required for tryptophan biosynthesis was fully expressed in $E$. coli (Bardowski et al., 1992).

\section{Amino acid sequence analysis}

The ORF encodes a polypeptide of 470 amino acids (see Fig. 2) that is similar in size $(50937 \mathrm{Da})$ to the deduced $p a b B$ gene products from $E$. coli $(53400 \mathrm{Da}$; Goncharoff $\&$ Nichols, 1984) and B. subtilis (approximately $50000 \mathrm{Da}$; Slock et al., 1990); its content of hydrophobic $(45.3 \%)$, hydrophillic $(36.5 \%)$, basic $(8.9 \%)$ and acidic $(8.8 \%)$ amino acids is similar to that reported for $E$. coli PabB (Goncharoff \& Nichols, 1984). The product of the L. lactis ORF shares substantial sequence identity with PabB of other organisms and also with the TrpE polypeptide of several bacteria, including that of $L$. lactis subspecies lactis (Table 1). The closest identity was with PabB of $S$. lividans. The presence of a single ORF encoding a polypeptide comparable to $\mathrm{PabB}$ in $E$. coli explains the complementation of $p a b B$ but not $p a b A$ mutations in that organism. The similarity of the L. lactis PabB to TrpE as well as to PabB polypeptides from various bacteria (Fig. 3) is consistent with the evidence from enteric bacteria that PabB and TrpE are very similar (Goncharoff \& Nichols, 1988), and with the suggestion by these and other workers (Crawford, 1989) that the $p a b$ and $\operatorname{tr} p$ genes coding for the polypeptides evolved from a common ancestor. As observed by Crawford (1989) for other PabB and TrpE sequences, alignment of identical and similar amino acids was markedly better in the carboxy-terminal than in the amino-terminal halves of the polypeptides. It is noteworthy that the deduced amino acid sequence for $p a b B$ of $L$. lactis showed a similar degree of identity to the sequences deduced for $\operatorname{trp} E$ from the same organism $(41 \%)$, from B. subtilis $(43 \%)$ and from Pseudomonas aeruginosa $(46 \%)$; moreover, this identity was consistently lower than with sequences deduced for $p a b B$ from various bacteria.

No additional ORFs were detected in the $1.87 \mathrm{~kb}$ fragment of $L$. lactis DNA; therefore, the organization of PABA synthase genes differs from that in $B$. subtilis where $p a b B$, an amphibolic $p a b A / \operatorname{trp} G$ and $p a b C$ are translationally coupled as part of a presumptive operon directing folic acid biosynthesis (Slock et al., 1990). It also differs from that in $S$. lividans where $p a b B$ and $p a b A$ are closely linked but separate from $p a b C$ (Arhin \& Vining, 1993). If $p a b A$ and $p a b C$ have separate locations, the distribution of PABA synthase genes in L. lactis subsp. lactis would resemble that in enteric bacteria (Bachmann, 1990). The apparent absence in L. lactis of a cluster containing all PABA synthetase genes contrasts with the adjacent arrangement in that organism of the genes for tryptophan biosynthesis, an arrangement which, in several respects, also resembles that in the Enterobacteriaceae (Bardowski et al., 1992).

\section{Codon usage in the ORF}

The $41.4 \% \mathrm{G}+\mathrm{C}$ content of the coding region in the cloned L. lactis DNA is somewhat higher than the $37 \%$ overall $\mathrm{G}+\mathrm{C}$ content in the DNA of the genome (Schleifer et al., 1985). Table 2 shows the expected biassed use of synonymous codons rich in $\mathrm{A}$ and $\mathrm{T}$ nucleotides. Consistent with this preference, the first position in the codons averages $49 \cdot 3 \% \mathrm{G}+\mathrm{C}$, the second position $39.7 \%$ and the degenerate third position only $34.9 \%$. Use 


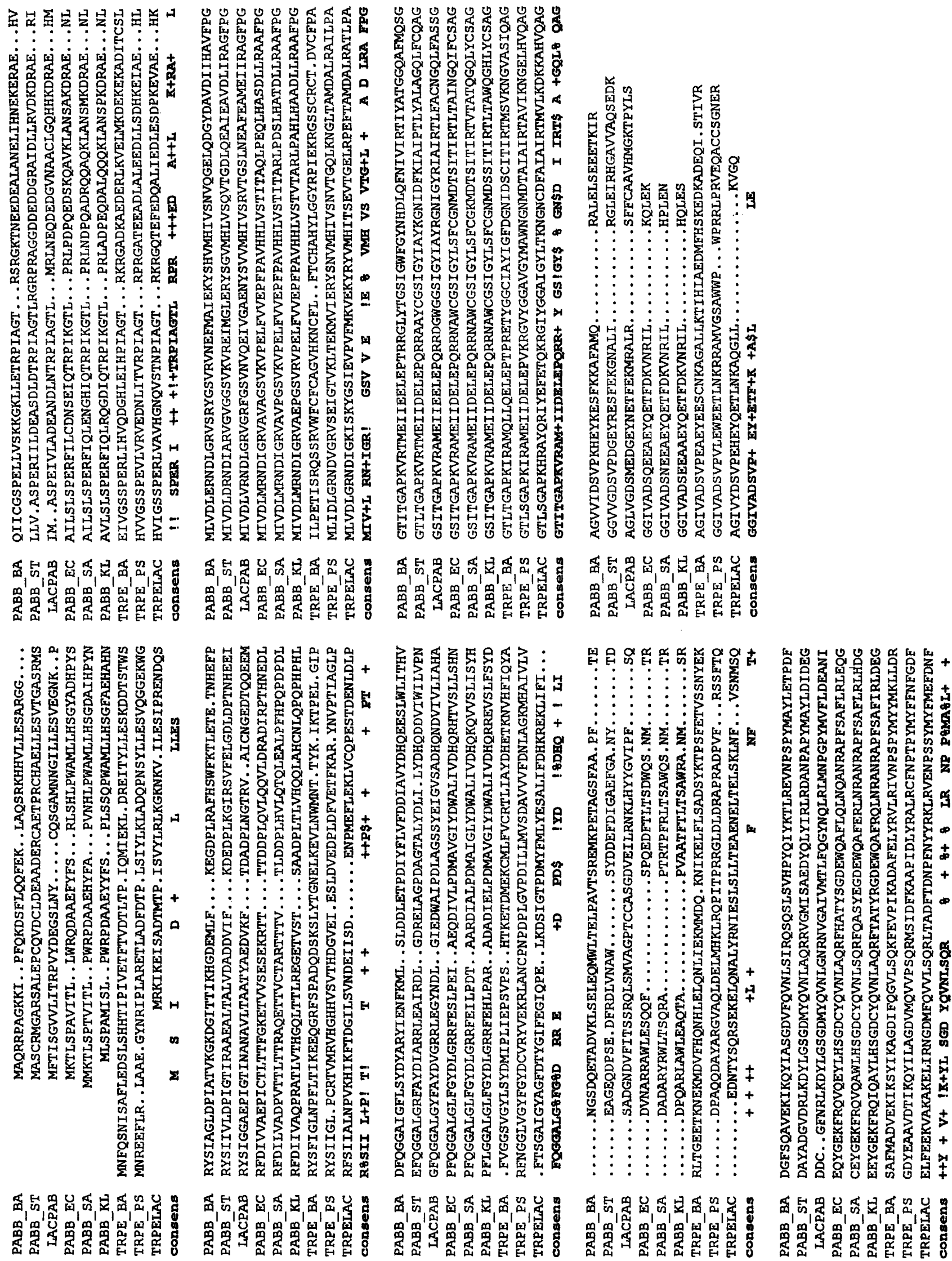


Table 2. Codon usage in L. lactis pabB and S. lividans genes

Frequencies in 15 sequenced genes from S. lividans JI1326 were calculated using the CODONFREQUENCY program in software from Genetics Computer Group Inc., Madison, WI, USA. The genes (and accession numbers) were: celA (M82807), cmlG (X59968), lrm/mgt (M74717), pabA/pabB (M64859), P49/XP55(Y00142), snpA/snpR (M81703), tet (M74079, tipA (M24524), $x \ln A$ (M64551), $x \ln B$ (M64552) and $x \ln C$ (M64553).

\begin{tabular}{|c|c|c|c|c|c|c|c|}
\hline \multicolumn{2}{|c|}{ Codon } & \multirow{3}{*}{$\begin{array}{l}\text { L. lactis } \\
\begin{array}{l}0 \\
1.00\end{array}\end{array}$} & \multirow{3}{*}{$\begin{array}{c}\begin{array}{c}S . \\
\text { lividans }\end{array} \\
0.01 \\
0.99\end{array}$} & \multicolumn{2}{|c|}{ Codon } & \multirow{3}{*}{$\begin{array}{l}\text { L. lactis } \\
\begin{array}{l}0 \\
1.00\end{array}\end{array}$} & \multirow{2}{*}{$\begin{array}{c}\begin{array}{c}S . \\
\text { lividans }\end{array} \\
0.02 \\
0.98\end{array}$} \\
\hline Phe & UUU & & & \multirow[t]{2}{*}{ Tyr } & UAU & & \\
\hline Leu & $\begin{array}{l}\text { UUC } \\
\text { UUA }\end{array}$ & & & & UAC & & \\
\hline Leu & UUG & 0.97 & 0.3 & ter & UAG & 0 & 0.07 \\
\hline \multirow[t]{4}{*}{ Leu } & CUU & 0 & 0.02 & \multirow[t]{2}{*}{ His } & CAU & 1.00 & 0.03 \\
\hline & CUC & 0 & 0.36 & & CAC & & 0.97 \\
\hline & CUA & 0 & 0.01 & \multirow[t]{2}{*}{ Gin } & CAA & 0.93 & 0.05 \\
\hline & CUG & 0.03 & 0.59 & & CAG & 0.07 & 0.95 \\
\hline \multirow[t]{3}{*}{ Ile } & AUU & & 0.02 & \multirow[t]{2}{*}{ Asn } & AAU & 0.03 & 0.01 \\
\hline & AUC & 0.97 & 0.95 & & $\mathrm{AAC}$ & 0.97 & 0.99 \\
\hline & AUA & 0.03 & 0.03 & \multirow[t]{2}{*}{ Lys } & $\mathrm{AAA}$ & & 0.04 \\
\hline Met & AUG & 1.00 & 1.00 & & AAG & 1.00 & 0.96 \\
\hline \multirow[t]{4}{*}{ Val } & GUU & 0 & 0.01 & \multirow[t]{2}{*}{ Asp } & GAU & 0.97 & 0.03 \\
\hline & GUC & 0 & 0.60 & & GAC & 0.03 & 0.97 \\
\hline & GUA & 0.97 & 0.03 & \multirow[t]{2}{*}{ Glu } & GAA & 0.97 & $0 \cdot 14$ \\
\hline & GUG & 0.03 & 0.36 & & GAG & 0.03 & 0.86 \\
\hline \multirow[t]{4}{*}{ Ser } & UCU & 0 & 0.01 & \multirow{2}{*}{ Cys } & UGU & 1.00 & 0.07 \\
\hline & UCC & 0.04 & 0.34 & & UGC & & 0.93 \\
\hline & UCA & 0 & 0.01 & \multirow{2}{*}{$\begin{array}{l}\text { ter } \\
\text { Trp }\end{array}$} & UGA & & 0.93 \\
\hline & UCG & 0 & 0.26 & & UGG & 1.00 & 1.00 \\
\hline \multirow[t]{4}{*}{ Pro } & $\mathrm{CCU}$ & 0.20 & 0.02 & \multirow[t]{4}{*}{ Arg } & CGU & 0 & 0.06 \\
\hline & $\mathrm{CCC}$ & 0 & 0.40 & & CGC & 0 & 0.47 \\
\hline & $\mathrm{CCA}$ & 0.73 & 0.03 & & CGA & 0.08 & 0.04 \\
\hline & $\mathrm{CCG}$ & 0.07 & 0.54 & & CGG & 0 & 0.36 \\
\hline \multirow[t]{4}{*}{ Thr } & $\mathrm{ACU}$ & 0.33 & 0.02 & \multirow[t]{2}{*}{ Ser } & AGU & 0.96 & 0.05 \\
\hline & $\mathrm{ACC}$ & & 0.64 & & AGC & & 0.34 \\
\hline & $\mathrm{ACA}$ & 0.67 & 0.03 & \multirow[t]{2}{*}{ Arg } & AGA & 0.92 & 0.01 \\
\hline & ACG & 0 & 0.31 & & AGG & 0 & 0.06 \\
\hline \multirow[t]{4}{*}{ Ala } & GCU & 0.05 & 0.01 & \multirow[t]{4}{*}{ Gly } & GGU & 0.02 & 0.07 \\
\hline & GCC & & 0.56 & & GGC & & 0.71 \\
\hline & GCA & 0.93 & 0.04 & & GGA & 0.98 & 0.08 \\
\hline & GCG & 0.02 & 0.38 & & GGG & 0 & $0 \cdot 13$ \\
\hline
\end{tabular}

of the termination codon TAA instead of TGA or TAG follows the trend towards codons with low $\mathrm{G}+\mathrm{C}$ content.

A comparison of codon usage in the L. lactis pabB ORF with the average usage in 15 genes cloned from $S$. lividans shows sharp differences between the two bacteria (Table 2). Since the genes included are unlikely to be highly expressed, the distribution of isoaccepting tRNA species in S. lividans may be even more polarized than is suggested by the synonymous codon usage data (Wright $\&$ Bibb, 1992). The potential imbalance between specific tRNA availability and codon preference did not prevent expression of the cloned L. lactis pabB in S. lividans at a level that reversed sulphanilamide inhibition through overproduction of PABA. This result extends the variety of examples where streptomycetes, and notably $S$. lividans, has been used as the host for expressing genes cloned in recombinant vectors. It confirms earlier evidence (Pulido et al., 1986) that the codon usage bias in $S$. lividans does not preclude expression of genes from organisms with markedly different codon preferences. Andersson \& Kurland (1990) have pointed out that the overall frequency with which an mRNA is translated depends more upon its ability to initiate protein synthesis by sequestering ribosomal components than on the rate at which the message is subsequently translated; codon preference could potentially limit the rate at which a gene is expressed, but this too might be offset by mechanisms regulating the expression of individual isoaccepting tRNAs. At present there is no evidence that the degree to which codon preferences match the distribution of isoaccepting tRNAs controls gene expression.

This work was supported by the Natural Sciences and Engineering Research Council of Canada. F.F.A. received scholarship support from the Killam Memorial Trust and the Faculty of Graduate Studies, Dalhousie University. We thank Drs D. A. Hopwood, John Innes Institute, Norwich, UK, J. A. Gil, Universidad de Léon, Spain and B. J. Bachmann, Yale University School of Medicine, New Haven, CT, USA for generously providing cultures. We are also grateful to $\mathrm{S}$. J. Lucania, E. R. Squibb and Sons, New Brunswick, NJ, USA for a gift of thiostrepton.

\section{References}

AIDoo, D. A. (1985). A study of plasmids and nisin production in $S$. lactis. MSc thesis, Dalhousie University, Canada.

Aidoo, D. A., BarretT, K. \& VINING, L. C. (1990). Plasmid transformation of Streptomyces venezuelae: modified procedures used to introduce the gene(s) for $p$-aminobenzoate synthetase. Journal of General Microbiology 136, 657-662.

Altschul, S. F., Gish, W., Miller, W., Myers, E. W. \& Lipman, D. J. (1990). Basic local alignment search tool. Journal of Molecular Biology 215, 403-410.

ANDERson, D. G. \& McKay, L. L. (1983). Simple and rapid method for isolating large plasmid DNA from lactic streptococci. Applied and Environmental Microbiology 46, 549-552.

ANDERSSON, S. G. E. \& KuRLAND, C. G. (1990). Codon preferences in free-living microorganisms. Microbiological Reviews 54, 198-210.

Fig. 3 (facing page). Alignment of PabB and TrpE proteins from Bacillus subtilis (BA), Streptomyces lividans (ST), Lactococcus lactis subsp. lactis (LAC), Escherichia coli (EC), Salmonella typhimurium (SA), Klebsiella aerogenes (KL) and Pseudomonas aeruginosa (PS). Sequences were analysed by the MULTALIN programme (Corpet, 1988). Amino acids identical in a large majority of the sequences are printed in the consensus line; similar residues are identified as ! (I or V), $\$(L$ or $M), \%(F$ or $Y)$ and $+(B, D, E, N, Q$, or Z). Dots indicate gaps introduced to increase similarity (gap penalty 8 ). 
ARHIN, F. F. \& VINING, L. C. (1993). Organization of the genes encoding $p$-aminobenzoic acid synthetase from Streptomyces lividans 1326. Gene 126, 129-133.

BACHMANN, B. J. (1990). Linkage map of Escherichia coli K12, Edition 8. Microbiological Reviews 54, 130-197.

BaLTZ, R. H. (1990). Gene expression using streptomycetes. Current Opinion in Biotechnology 1, 12-20.

BardowsKi, J., Ehrlich, S. D. \& Chopin, A. (1992). Tryptophan biosynthesis genes in Lactococcus lactis subsp. lactis. Journal of Bacteriology 174, 6563-6570.

BIBB, M. J. \& CoHEN, S. N. (1982). Gene expression in Streptomyces: construction and application of promoter-probe plasmid vectors in Streptomyces lividans. Molecular and General Genetics 187, 265-277.

Bibb, M. J., Chater, K. F. \& Hopwood, D. A. (1983). Developments in Streptomyces cloning. In Experimental Manipulations of Gene Expression, pp. 53-82. Edited by M. Inouye. London: Academic Press.

Bibb, M. J., Bibb, M. J., Ward, J. M. \& Cohen, S. N. (1985). Nucleotide sequences encoding and promoting expression of three antibiotic resistance genes indigenous to Streptomyces. Molecular and General Genetics 199, 26-36.

Chang, S.-Y. \& Chang, S. (1988). Secretion of heterologous proteins in Streptomyces lividans. In Biology of Actinomycetes ' $88, \mathrm{pp}$. 103-107. Edited by Y. Okami, T. Beppu \& H. Ogawara. Tokyo: Japan Scientific Societies Press.

Chater, K. F., Bruton, C. J., King, A. A. \& Suarez, J. E. (1982). The expression of Streptomyces and Escherichia coli drug resistance determinants cloned into the Streptomyces phage $\nsim \mathrm{C} 31$. Gene 19, 21-32.

Chatterjee, S., Vining, L. C. \& Westlake, D. W. S. (1983). Nutritional requirements for chloramphenicol biosynthesis in Streptomyces venezuelae. Canadian Journal of Microbiology 28, 311-317.

CORPET, F. (1988). Multiple sequence alignment with hierarchical clustering. Nucleic Acids Research 16, 10881-10890.

CRAWFORD, I. P. (1989). Evolution of a biosynthetic pathway: the tryptophan paradigm. Annual Reviews of Microbiology 43, 567-600.

Criado, L. M., MarTiN, J.-F. \& Gil, J. A. (1993). The pab gene of Streptomyces griseus encoding $p$-aminobenzoic acid synthase is located between genes possibly involved in candicidin biosynthesis. Gene 126, 135-139.

David, S., VAN DER Rest, M. E., Drissen, A. J. M., Simons, G. \& DE Vos, W. M. (1990). Nucleotide sequence and expression in Escherichia coli of the Lactococcus lactis citrate permease gene. Journal of Bacteriology 172, 5789-5794.

Delorme, C., Ehrlich, S. D. \& Renault, P. (1992). Histidine biosynthesis genes in Lactococcus lactis subsp. lactis. Journal of Bacteriology 174, 6571-6579.

DENHARDT, D. T. (1966). A membrane filter technique for the detection of complementary DNA. Biochemical and Biophysical Research Communications 23, 641-646.

DE Vos, W. M. (1987). Gene cloning and expression in lactic streptococci. FEMS Microbiology Reviews 46, 281-295.

Essar, D. W., Eberly, L., Han, C.-Y. \& CraWFord, I. P. (1990). DNA sequences and characterization of four early genes of the tryptophan pathway in Pseudomonas aeruginosa. Journal of Bacteriology 172, 853-866.

GIL, J. A. \& HopwOOD, D. A. (1983). Cloning and expression of a paminobenzoic acid synthetase gene of the candicidin-producing Streptomyces griseus. Gene 25, 119-132.

Godon, J.-J., ChOPIN, M.-C. \& EHRLICH, S. D. (1992). Branched-chain amino acid and biosynthesis genes in Lactococcus lactis subsp. lactis. Journal of Bacteriology 174, 6580-6589.

GoncharofF, P. \& Nichols, B. P. (1984). Nucleotide sequence of Escherichia coli pabB indicates a common evolutionary origin of $p$ aminobenzoate and anthranilate synthetase. Journal of Biological Chemistry 159, 57-62.

GonChaROFF, P. \& Nichols, B. P. (1988). Evolution of aminobenzoate synthetases: nucleotide sequences of Salmonella typhimurium and Klebsiella aerogenes pabB. Molecular Biology and Evolution 5, 531-548.

Gray, G., Selzer, G., Bull, G., Shaw, P., Escarez, S., Hofer S.,
Voegeli, P. \& Thompson, C. J. (1984). Synthesis of bovine growth hormone by Streptomyces lividans. Gene 32, 21-30.

HENNER, D. J., BAND, L. \& SHMOTSU, H. (1984). Nucleotide sequence of the Bacillus subtilis trytophan operon. Gene 34, 169-177.

Hopwood, D. A. (1967). Genetic analysis and genome structure in Streptomyces coelicolor. Bacteriological Reviews 31, 373-403.

Hopwood, D. A., BibB, M. J., Chater, K. F., Kieser, T., Bruton, C. J., Kieser, H. M., Lydiate, D. J., Thompson, C. J., Smith, C. P., WARD, J. M. \& SCHREMPF, H. (1985). Genetic Manipulation of Streptomyces: a Laboratory Manual. Norwich: John Innes Foundation.

Hopwood, D. A., Bibb, M. J., Chater, K. F., Janssen, G. R., Malpartida, F. \& SMITH, C. P. (1986). Regulation of gene expression in antibiotic producing streptomycetes. Symposia of the Society of General Microbiology 39, 251-276.

Hopwood, D. A., BibB, M. J., Chater, K. F. \& Kieser, T. (1987). Plasmid and phage vectors for gene cloning and analysis in Streptomyces. Methods in Enzymology 1553, 116-165.

HuNTER, I. S. (1985). Gene cloning in Streptomyces. In DNA Cloning, vol. 2, chapter 2, pp. 19-44. Edited by D. M. Glover. Oxford: IRL Press.

IKEMURA, T. (1981). Correlation between the abundance of Escherichia coli transfer RNAs and the occurrence of the respective codons in its protein genes. Journal of Molecular Biology 146, 1-21.

IraNI, M., Mosso, R. \& ADHYA, S. (1989). Cyclic-AMP-dependent switch in initiation of transcription from two promoters of the Escherichia coli gal operon: identification and assay of 5 -triphosphate ends of mRNA by GTP: RNA guanyltransferase. Journal of Bacteriology 171, 1623-1630.

KARGER, B. D. \& Jessee, J. (1990). Preparation of single strand DNA from phagemids. Focus 12, 28-29.

KIESER, T. (1984). Factors affecting the isolation of cccDNA from Streptomyces lividans and Escherichia coli. Plasmid 12, 19-36.

Koller, K.-P., Riess, G., Sauber, K., Willmann, E. \& Wallmeier, H. (1989). Recombinant Streptomyces lividans secretes a fusion protein of tendamistat and proinsulin. Bio/Technology 7, 1055-1059.

Kunstos, S. \& RAO, R. N. (1983). Expression in Streptomyces ambofaciens of an Escherichia coli K-12 gene which confers resistance to hygromycin B. Gene 26, 295-299.

LEVINE, J. \& FisCHBACH, H. (1951). The chemical determination of chloramphenicol in biological materials. Antibiotics and Chemotherapy 1, 59-62.

Lichenstein, H., Brawner, M. E., Miles, L. M., Meyers, C. A., Young, P. R., Simon, P. L. \& ECKHARDT, T. (1988). Secretion of interleukin-1- $\beta$ and Escherichia coli galactokinase by Streptomyces lividans. Journal of Bacteriology 170, 3924-3929.

LudWig, W., Seewaldt, E., KilpPer-Bälz, R., Schleifer, K. H., Magrum, L., Woese, C. R., FoX, G. E. \& StackebrandT, E. (1985). The phylogenetic position of Streptococcus and Enterococcus. Journal of General Microbiology 131, 543-551.

MCCLURE, W. R. (1985). Mechanism and control of transcription initiation in prokaryotes. Annual Review of Biochemistry 54, 171-204.

Malek, L. T., Soustmeyer, G., Davey, C., Krygsmers, P., Compton, J., ZIMNY, T. \& STEWART, D. (1990). Secretion of granulocyte macrophage-colony stimulating factor (GM-CSF) in Streptomyces lividans. Journal of Cellular Biochemistry Supplement 14A, 127.

Muñoz, A., Perez-Aranda, A. \& Barbero, J. L. (1985). Cloning and expression of human interleukin-2 in Streptomyces lividans using the Escherichia coli consensus promoter. Biochemical and Biophysical Research Communication 133, 511-519.

PARADKAR, A. S. (1991). Molecular genetics of tryptophan biosynthesis in Streptomyces venezuelae ISP5230. PhD thesis, Dalhousie University, Canada.

Prival, M. J. \& Magasanik, B. (1971). Resistance to catabolite repression of histidase and proline oxidase during nitrogen-limited growth of Klebsiella aerogenes. Journal of Biological Chemistry 246, 6288-6296.

Pulido, D., Vara, J. A. \& Jimenez, A. (1986). Cloning and expression in biologically active form of the gene for human interferon $\alpha 2$ in Streptomyces lividans. Gene 45, 167-174.

ROSENBERG, M. \& COURT, D. (1979). Regulatory sequences involved in 
the promotion and termination of RNA transcription. Annual Review of Genetics 13, 319-353.

SANGER, F., Nicklen, S. \& Coulson, A. R. (1977). DNA sequencing with chain terminating inhibitors. Proceedings of the National Academy of Sciences of the United States of America 74, 5463-5467.

Schleifer, K. H., Kraus, J., Dvorak, C., Kilpper-Baelz, R., Collins, M. D. \& Fischer, W. (1985). Transfer of Streptococcus lactis and related streptococci to the genus Lactococcus gen. nov. Systematic and Applied Microbiology 6, 183-195.

Schottel, J. L., BibB, M. J. \& CoheN, S. N. (1981). Cloning and expression in Streptomyces lividans of antibiotic resistance genes derived from Escherichia coli. Journal of Bacteriology 146, 360-368.

SENO, E. T. \& BALTZ, R. H. (1991). Structural organization and regulation of antibiotic biosynthesis and resistance genes in actinomycetes. In Regulation of Secondary Metabolism in Actinomycetes, pp. 1-48. Edited by S. Shapiro. Boca Raton, FL: CRC Press.

Shareck, F., Sasarman, A. \& Vezina, C. (1984). Construction of a shuttle vector and expression in Streptomyces lividans of the sulfonamide-resistance gene derived from Escherichia coli plasmid pSAS1206. Canadian Journal of Microbiology 30, 515-518.

Slock, J., Stahly, D. P., Han, C.-Y., SiX, E. W. \& CraWford, I. P.
(1990). An apparent Bacillus subtilis folic acid biosynthetic operon containing $p a b$, an amphibolic $\operatorname{trp} G$ gene, a third gene required for biosynthesis of para-aminobenzoic acid and the dihydropteroate synthetase gene. Journal of Bacteriology 172, 7211-7226.

STACKeBRANDT, E. \& WoESE, C. R. (1981). Towards a phylogeny of the actinomycetes and related organisms. Current Microbiology 5 , 197-202.

STrOHL, W. R. (1992). Compilation and analysis of DNA sequences associated with apparent streptomycete promoters. Nucleic Acids Research 20, 961-974.

TомICH, P. K. (1988). Streptomyces cloning: useful recombinant DNA systems and a summation of cloned genes. Antimicrobial Agents and Chemotherapy 32, 1465-1471.

TERZAGHI, B. E. \& SANDINE, W. E. (1975). Improved medium for lactic streptococci and their bacteriophages. Applied and Environmental Microbiology 29, 807-813.

Thompson, C. J., Kieser, T., WaRd, J. M. \& Hopwood, D. A. (1982a). Physical analysis of antibiotic resistance genes from Streptomyces and their use in vector construction. Gene 20, 51-62.

Wright, F. \& BiBB, M. J. (1992). Codon usage in the G+C-rich Streptomyces genome. Gene 113, 55-65. 